\title{
New constraints on the origin of Roberts Victor eclogites: geochemical evidence for a subducted arc or back-arc basalt protolith
}

\author{
Judith A. Coggon ${ }^{1}$, Iain McDonald ${ }^{2}$, D. Graham Pearson ${ }^{1}$ and Akira Ishikawa ${ }^{1}$ \\ ${ }^{1}$ Department of Earth Sciences, Durham University, Durham, UK \\ ${ }^{2}$ School of Earth, Ocean and Planetary Sciences, Cardiff University, Cardiff, UK
}

\begin{abstract}
Introduction
Two scenarios of formation are prevalent in the debate over the origin of deep mantle eclogites. The first proposes that the eclogite protoliths were Proterozoic and Archean oceanic basalts and gabbroic cumulates that were subducted and accreted to the peridotitic bases of the cratons (e.g. MacGregor and Manton, 1986). Alternatively it has been suggested that eclogite is formed beneath cratons in a process that occurs at pressures in excess of $3 \mathrm{GPa}$. This involves accumulation from deep-mantle melts of an anomalous, hyperaluminous pyroxene, followed by exsolution of kyanite, garnet and sometimes silica due to decreasing in temperature (O’Hara and Yoder, 1967).
\end{abstract}

Much of the above debate has centred around the Roberts Victor eclogite suite due to the large size and abundance of eclogites formerly available from this mine. A subduction origin for eclogites from this location has become the favoured hypothesis due to convincing arguments based on $\delta \mathrm{O}^{18}$ data, REE patterns, and Eu anomalies (e.g. Jagoutz et al., 1984; Schulze et al., 2000; and Jacob et al., 2003). Jacob et al. (2003) invoked oceanic gabbroic cumulate protoliths for the coesite-bearing eclogites from Roberts Victor. Here we present new trace element and Re-Os isotope data for a suite of eclogites from this kimberlite with the aim of further evaluating their origin, specifically attempting to identify the likely protoliths.

\section{Samples and regional geology}

The Roberts Victor kimberlite is situated in the centre of the Kaapvaal craton and lies on the Colesberg magnetic lineament. This lineament is thought to represent a collisional suture between the Kimberley and Witwatersrand blocks, which converged approximately 2.9 billion years ago. Suturing was accommodated by subduction and terrane collision (Schmitz et al. 2004).

A suite of 12 bimineralic eclogites, classified as Group I and II were analysed for whole-rock major and trace elements by ICP-OES and ICP-MS. In seven of the xenoliths, garnets and clinopyroxenes were analysed for REE by Laser Ablation-ICP-MS. 'Reconstructed bulk-rock' trace element concentrations were produced by combining modal mineral proportions with LA-ICP-
MS data generated on garnet and clinopyroxene. Re-Os isotopes were measured for nine of the samples, by negative-TIMS.

\section{Elemental geochemistry}

All 12 eclogites analysed have 1 atmosphere CIPW normative assemblages containing considerable amounts of plagioclase $(\sim 30-60 \mathrm{wt} \%)$ and between approximately 17 and 38 wt \% olivine. None of the samples have normative quartz. Five of the xenoliths (RV-IM-09, -10, -12, -13 and -17) are nepheline normative and thus can be classified as having protoliths of alkali basaltic compositions. The remaining seven xenoliths contain normative hypersthene, thus, chemically they resemble olivine tholeiites. Interestingly, samples with olivine tholeiite normative compositions are classed as Group I eclogites, while those with alkalic normative assemblages fall within Group II.

Whole-rock $\mathrm{MgO}$ contents range from 10.06 - 14.84 wt $\%$, with Group I xenoliths being generally more $\mathrm{MgO}$-rich. In comparison, published $\mathrm{MgO}$ data for potential protoliths are as follows: oceanic gabbros, $\sim 4$ $-12 \mathrm{wt} \%$; komatiites and basaltic komatiites, $>\sim 10$ wt $\%$; MORB, $\sim 5-10 \mathrm{wt} \%$; and Archean picrites and komatiites, $\sim 17.5-25 \mathrm{wt} \%$ (Wilson, 1989).

\begin{tabular}{lcc}
\hline $\begin{array}{c}\text { Element } \\
(\text { wt \%) }\end{array}$ & $\begin{array}{c}\text { Mean Roberts Victor } \\
\text { Eclogites }\end{array}$ & $\begin{array}{c}\text { Mean Grenada } \\
\text { Picrites }\end{array}$ \\
\hline $\mathrm{SiO}_{2}$ & 44.71 & 46.02 \\
$\mathrm{Al}_{2} \mathrm{O}_{3}$ & 16.60 & 13.78 \\
$\mathrm{Fe}_{2} \mathrm{O}_{3}$ & 12.73 & 10.24 \\
$\mathrm{MgO}$ & 12.70 & 14.06 \\
$\mathrm{CaO}$ & 9.00 & 11.65 \\
$\mathrm{Na}_{2} \mathrm{O}$ & 1.88 & 1.99 \\
$\mathrm{~K}_{2} \mathrm{O}$ & 0.52 & 0.63 \\
$\mathrm{TiO}_{2}$ & 0.40 & 0.94 \\
$\mathrm{MnO}$ & 0.25 & 0.17 \\
$\mathrm{P}_{2} \mathrm{O}_{5}$ & 0.05 & 0.20 \\
$\mathrm{Total}$ & 98.83 & 99.63 \\
\hline
\end{tabular}

Table 1. Mean major element composition of Roberts Victor eclogites (this study) and Grenada arc picrites (Woodland et al., 2002).

$\mathrm{SiO}_{2}$ contents of the eclogite suite are low (40.19 48.42 wt \%) relative to MORB and oceanic gabbros, but fall within the range of komatiites and basaltic komatiites. All of the xenoliths are relatively rich in $\mathrm{Al}_{2} \mathrm{O}_{3} \quad(11.21-20.62$ wt $\%)$, while, $\mathrm{TiO}_{2}$ concentrations are low $(0.22-0.50 \mathrm{wt} \%)$. Over all, the whole-rock major element compositions of this suite of 
eclogites strongly resemble those of a suite of picrites from Grenada, in the Lesser Antilles arc (Table 1) (Woodland et al., 2002), presuming no mantle-based modification of major element chemistry has taken place.

The Roberts Victor eclogites have flat reconstructed bulk-rock HREE patterns with relative depletion in the LREEs (mean $\mathrm{La} / \mathrm{YbN}=0.361$ ). Positive Eu anomalies in the reconstructed eclogite trace element compositions (Figure 1) indicate that the protoliths of these eclogites have, at some time, experienced plagioclase fractionation in a low pressure environment $(<0.6 \mathrm{GPa})$.

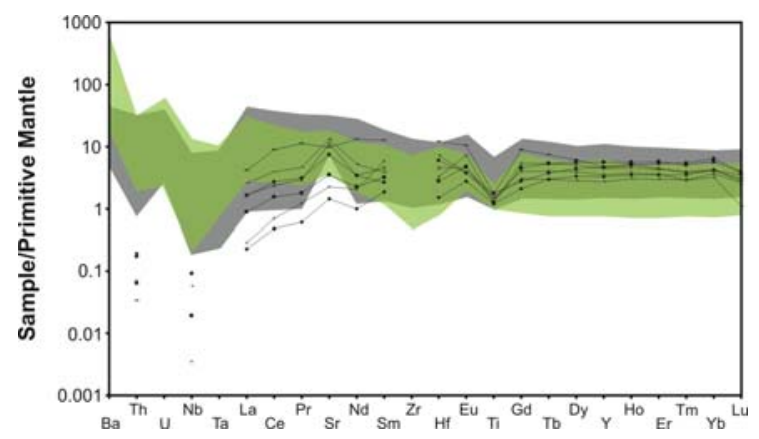

Figure 1. Trace element patterns for RV reconstructed bulk eclogite, normalised to primitive mantle (Sun and McDonough, 1989). Green shaded area $=$ measured bulk-rock for RV suite, grey shaded area $=$ New Britain Arc bulk-rock (Woodhead et al., 1998).

Mantle normalised multi-element plots of both measured and reconstructed bulk-rock data show strong negative anomalies in $\mathrm{Ta}, \mathrm{Nb}$, and $\mathrm{Ti}$ (mean $\mathrm{Nb} / \mathrm{LaN}=0.024$; mean $\mathrm{Ti} / \mathrm{Ti}^{*}=0.132$ ) and consistently positive anomalies for Sr. Similar $\mathrm{Sr}$ anomalies can be seen in other eclogite suites, however $\mathrm{Ta}, \mathrm{Nb}$, and $\mathrm{Ti}$ anomalies of such extreme magnitude are abnormal (Figure 1). The same pattern is seen in reconstructed bulk-rock data for rutile-bearing Roberts Victor coesite-eclogites (Jacob et al., 2003). In this case the authors state that the $\mathrm{Nb}, \mathrm{Ta}$ and $\mathrm{Ti}$ anomalies are "artificially low" since rutile was not used for the reconstructions where as in samples that were reconstructed allowing for rutile, positive $\mathrm{Nb}, \mathrm{Ta}$ and $\mathrm{Ti}$ anomalies are observed. However, in the case of the bimineralic eclogites of this study, $\mathrm{Nb}, \mathrm{Ta}$ and $\mathrm{Ti}$ depletion is also observed in measured bulk-rock, as mentioned above, though it is less pronounced. It is possible that the difference in concentration of these elements between measured and reconstructed bulkrock is due to the (unconfirmed) presence of very minor amounts of rutile; alternatively it may be a product of contamination with Ti-bearing phlogopite by the host kimberlite (Jacob et al., 2005), since phlogopite is observed along fractures and around the margins of these xenoliths, or a combination of both.

The eclogite trace element patterns are strikingly similar to those observed for basalts in modern arc (Woodhead et al., 1998; Woodland et al., 2002) and back-arc environments (e.g. Pearce et al., 1995), not only in shape but also in the range of normalised concentrations displayed (Figure 1).

\section{Re-Os isotopes and abundances}

Re contents of the Roberts Victor eclogites span approximately the same range as Alpine gabbroic eclogites ( 100 - 1000 ppt; Dale et al., 2007). However, Os concentrations are relatively high (Os, 48 - 702 ppt) and exceed Alpine eclogite values (Figure 2) such that Roberts Victor eclogite $\mathrm{Re} / \mathrm{Os}$ ratios are lower. Grenada picrites are very low in Re but their Os contents overlap with those of the Roberts Victor samples (Woodland et al., 2002). Re concentrations in komatiites from Alexo, Ontario fall within the range of the Roberts Victor samples and their Os contents also overlap the Roberts Victor range (Gangopadhyay and Walker, 2003). However, Commondale komatiitic lavas from the Southern Kaapvaal Craton have lower Re and higher Os than the eclogites (Wilson et al., 2003), and consequently lower Re/Os ratios (Figure 2).

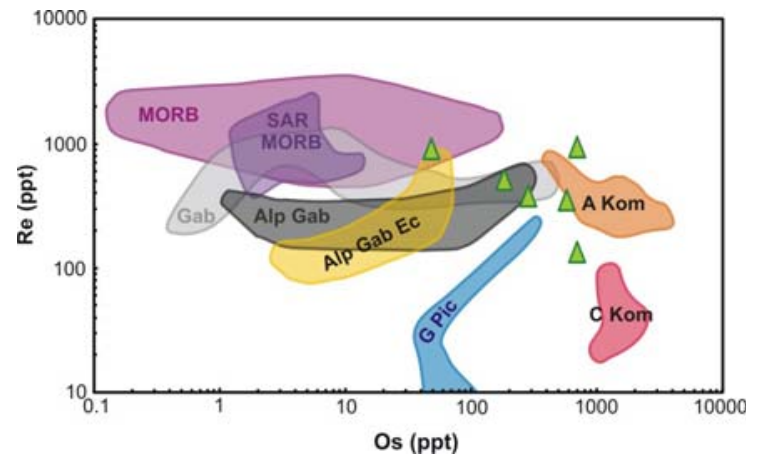

Figure 2. Os vs. Re for six Roberts Victor eclogites. Fields as follows: Purple, MORB (Schiano et al.,1997); dark purple, MORB glasses, South Atlantic Ridge (Escrig et al., 2005); light grey, Gabbros - ODP Site 735B (Blusztajn et al., 2000); dark grey, Alpine gabbros; yellow, Alpine gabbroic eclogites (Dale et al,. 2007); orange, komatiites from Alexo, Ontario (Gangopadhyay and Walker, 2003); red, Commondale komatiitic lavas (Wilson et al., 2003); and blue, Grenada picrites (Woodland et al., 2002).

${ }^{187} \mathrm{Os} /{ }^{188} \mathrm{Os}$ and ${ }^{187} \mathrm{Re} /{ }^{188} \mathrm{Os}$ ratios (ranging between $0.33-1.03$ and $0.96-95.3$ respectively) match the patterns of other non-diamondiferous eclogites from the Kaapvaal Craton (Shirey et al., 2001). The relatively unradiogenic Os isotope ratios found in eclogites from Roberts Victor and in eclogites from the Kaapvaal craton in general contrast with the considerably more radiogenic ratios and requisite higher time-integrated Re/Os ratios displayed by Siberian eclogites (Pearson et al., 1995).

Re-Os model ages scatter widely, suggesting some disturbance of the Re-Os system has occurred. The eclogite suite as a whole does not form an isochron but scatters across a wide range of ${ }^{187} \mathrm{Re} /{ }^{188} \mathrm{Os}$ values. One sample has highly elevated ${ }^{187} \mathrm{Re} /{ }^{188} \mathrm{Os}$, suggestive of recent $\mathrm{Re}$ gain. However, samples with lower ${ }^{187} \mathrm{Re} /{ }^{188}$ Os have a well correlated range of ${ }^{187} \mathrm{Os} /{ }^{188} \mathrm{Os}$ values that scatter around an 'isochron' of approximately $3 \mathrm{Ga}$ with an elevated initial ratio. Eclogite samples that show the most coherent Re-Os isotope variation belong to the group I classification, which is more commonly diamondiferous. This 
supports the general observation made by Shirey et al. (2001) that diamondiferous or Group I eclogites from a variety of locations show the least disturbed Re-Os isotope systematics.

\section{Discussion and genetic model}

The geochemical signatures of the Roberts Victor eclogites appear to have a strong crustal signature and both major element and trace element compositions match various rock suites associated with modern-day subduction zones, particularly those from island arcs. Examples of subducting back-arc basins are numerous in SE Asia today and subduction of arc rocks has been observed in modern collision zones (Macpherson et al., 2003). It has been postulated that genesis of the peridotitic root of the Kaapvaal craton took place via subduction in an arc environment (Parman et al., 2004; Simon et al., 2007; Pearson \& Wittig, 2008) Given this subduction association we believe it is reasonable to assume that arc rocks may also have been subducted in Archean collision zones.

It should be noted that we do not discount the low $\delta \mathrm{O}^{18}$ data presented by authors such as Jagoutz et al. (1984), Schulze et al. (2000) and Jacob et al. (2003) as strong evidence of hydrothermally altered gabbroic protoliths for mantle eclogites. However, subducted Archean oceanic crust is isotopically heterogeneous (as noted by Jacob et al., 2005), and, like modern oceanic crust, generated in a variety of tectonic environments, giving rise to diverse compositional variation. Hence we propose that the Roberts Victor biminerallic eclogites analysed in this study were formed from picritic basalts crystallised in an arc or back-arc environment. Subsequent subduction and terrane collision processes at $\sim 2.9 \mathrm{Ga}$ forced the $\mathrm{Ta}, \mathrm{Nb}$ and $\mathrm{Ti}$ depleted protoliths from their crustal environment to the base of the craton. Later extensive silicate metasomatism of the type described by Ishikawa et al. (this volume) acted to disturb Re-Os and other isotope systematics in many eclogites while the Group I eclogites appear to have mostly evaded this modification.

\section{References}

Blusztajn, J., Hart, S.R., Ravizza, G. and Dick, H.J.B. (2000) Platinum-group elements and Os isotopic characteristics of the lower oceanic crust. Chemical Geology, 168, 113-122.

Dale, C.W., Gannoun, A., Burton, K.W., Argles, T.W. and Parkinson, I.J. (2007) Earth and Planetary Science Letters, 253 211-225.

Escrig, S., Schiano, P., Schilling, J-G. and Allègre, C. (2005) Rhenium-osmium isotope systematics in MORB from the Southern Mid-Atlantic Ridge $\left(40^{\circ}-50^{\circ} \mathrm{S}\right)$. Earth and Planetary Science Letters, 235, 528-548.

Gangopadhyay, A. and Walker, R.J. (2003) Re-Os systematics of the ca. 2.7-Ga komatiites from Alexo, Ontario, Canada. Chemical Geology, 196, 147-162.

Ishikawa, A., Pearson, D.G., Maruyama, S., de Bruin, D. and Gurney, J.J. (2008) Compositional variability of the Roberts Victor eclogites: evidence for mantle metasomatism involving diamond dissolution. Extended Abstract No. 9IKC-A-00079 (this volume).

Jacob, D.E., Schmickler, B. and Schulze, D.J. (2003) Trace element geochemistry of coesite-bearing eclogites from the Roberts Victor kimberlite, Kaapvaal craton. Lithos, 71, 337-351.

Jacob, D.E., Bizimis, M. and Salters, V.J.M. (2005) Lu-Hf and geochemical systematics of recycled ancient oceanic crust: evidence from Roberts Victor eclogites. Contributions to Mineral Petrology, 146, 707-720.

Jagoutz,E., Dawson, J.B., Hoernes, S., Spettle, B. and Wänke, H. (1984) Anorthositic oceanic crust in the Archaen Earth. In: $15^{\text {th }}$ lunar and planetary science conference (abs), 395-396.

MacGregor, I.D. and Manton, W.I. (1986) Roberts Victor eclogites: ancient oceanic crust. Journal of Geophysical Researh, 91, 14063-14079

Macpherson, C.G., Forde, E.J., Hall, R. and Thirlwall, M.F. (2003) Geochemical evolution of magmatism in an arc-arc collision: the Halmahera and Sangihe arcs, eastern Indonesia. In: Larter, R.D. and Leat, P.T. Intra-Oceanic Subduction Systems: Tectonic and Magmatic Processes. Geological Society, London, Special Publications, 219, 207-220.

O'Hara, M.J. and Yoder, H.S. (1967) Formation and fractionation of basic magmas at high pressures. Scottish Journal of Geology, 3, 67-117.

Parman, S.W., Grove, T.L., Dann, J.C. and De Wit, M.J. (2004) A subduction origin for komatiites and cratonic lithospheric mantle. South African Journal of Geology, 107, 107-118

Pearce, J.A., Ernewein, M., Bloomer, S.H., Parson, L.M., Murton, B.J. anf Johnson, L.E. (1995) Geochemistry of Lau Basin volcanic rocks: influence of ridge segmentation and arc proximity. In: J.L. Smeelie (ed.) Volcanism Associated with Extension at Consuming Plate Margins. Geological Society, Special Publication, 81, 53-75.

Pearson, D.G., Snyder, G.A., Shirey, S.B., Taylor, L.A., Carlson, R.W. and Sobolev, N.V. (1995) Archean Re-Os age for Siberian eclogites and constraints on Archean tectonics. Nature, 374, 711 713.

Pearson D.G. \& Wittig N. (2008) Formation of Archean continental lithosphere and its diamonds: the root of the problem. Journal of the Geological Society, London, 165, 1-20.

Schiano, P., Birck, J.L. and Allègre, C.J. (1997) Osmium-strontiumneodymium-lead isotopic covariations in mid-oceanic ridge basalt glasses and the heterogeneity of the upper mantle. Earth and Planetary Science Letters, 150, 363-379.

Schmitz M.D., Bowring S.A., de Wit M.J. and Gartz V. (2004) Subduction and terrane collision stabilized the western Kaapvaal craton tectosphere 2.9 billion years ago. Earth and Planetary Science Letters, 222, 363-376.

Schulze, D.J., Valley, J.W. andSpicuzza, M.J. (2000) Coesite eclogites from the Roberts Victor kimberlite, South Africa Lithos, 54, 23-32

Shirey, S. B., Carlson, R.W., Richardson, S.H., Menzies, A., Gurney, J.J., Pearson, D.G., Harris, J.W. and Wiechert, U. (2001) Archaean emplacement of eclogitic components into the lithospheric mantle during formation of the Kaapvaal Craton. Geophysical Research Letters 28, 2509-2512.

Simon N.S.C., Carlson R.W., Pearson D.G., and Davies G.R. (2007) The origin and evolution of the Kaapvaal cratonic lithospheric mantle. Journal of Petrology, 48, 589-625.

Wilson, M. (1989) Igneous Petrogenesis, A Global Tectonic Approach. London, Unwin Hyman, 466 pp.

Wilson, A.H., Shirey, S.B. and Carlson, R.W. (2003) Archaean ultradepleted komatiites formed by hydrous melting of cratonic mantle. Letters to Nature, 423, 858-861.

Woodhead, J.D., Eggins, S.M. and Johnson, R.W. (1998) Magma genesis in the New Britain island arc: further insights into melting and mass transfer processes. Journal of Petrology, 39 $1641-1668$.

Woodland, S.J., Pearson, D.G. and Thirlwall, M.F. (2002) A Platinum Group Element and Re-Os isotope investigation of siderophile element recycling in subduction zones: comparison of Grenada, Lesser Antilles Arc, and the Izu-Bonin Arc. Journal of Petrology, 43, 171-198. 